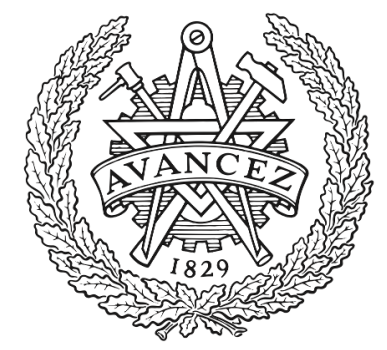

CHALMERS

UNIVERSITY OF TECHNOLOGY

\title{
Exploring differences between private and public organizations in business excellence models
}

Downloaded from: https://research.chalmers.se, 2023-04-26 13:30 UTC

Citation for the original published paper (version of record):

Raharjo, H., Eriksson, H. (2017). Exploring differences between private and public organizations in business excellence models. International Journal of Operations and Production Management, 37(12): 1795-1816. http://dx.doi.org/10.1108/IJOPM-09-2015-0593

N.B. When citing this work, cite the original published paper. 


\title{
Exploring differences between private and public organizations in business excellence models
}

Hendry Raharjo, Henrik Eriksson

Division of Quality Sciences, Department of Technology Management and Economics, Chalmers University of Technology, Gothenburg 41296, Sweden, hendry@chalmers.se; henrik.eriksson@chalmers.se

\begin{abstract}
Purpose

This study aims to explore the differences between public and private organizations in the paths of business excellence models and to identify the key drivers for creating business results and customer satisfaction.

\section{Design/methodology/approach}

The partial least squares structural equation modeling technique is used to compare the path coefficients and to identify the key driver constructs for creating business results.

\section{Findings}

The variation in endogenous constructs is found to be more difficult to explain or predict for private organizations than for public organizations, despite the fact that the performance of private organizations is almost always higher than or equal to the performance of public ones in all criteria. The effect of 'leadership' on 'management of processes' is significantly higher in public organizations than in private ones. However, 'management of processes' in public organizations does not seem to translate into 'results'. The effect of 'strategic planning' on creating business 'results' is negative for public organizations and remains inconclusive, due to insufficient evidence, for private organizations.
\end{abstract}

\section{Research limitations/implications}

The results may not be generally applicable to other countries. However, they do support the move toward more tailor-made models for specific sectors.

\section{Practical implications}

It is necessary to review the national business excellence model in order to fit specific sectors.

\section{Originality/value}

This is the first study to investigate the differences between private and public organizations in the Swedish business excellence model.

Keywords: Business excellence, quality award, public organization, private organization, multi-group analysis, importance-performance analysis

Article classification: Research paper 


\section{Introduction}

Sousa and Voss (2002) argued that research on quality management (QM) needs to understand the application of QM in different industries; in other words, more contingency research is needed. The use of management models that come from private sectors (e.g. QM) in public organizations has faced extensive criticism. Although public and private organizations have many similarities, there are also differences; for example, concerning the source of financial resources, ownership, and model of social control (Perry and Rainey, 1988; Hvidman \& Andersen, 2014). Boyne (2002, p. 97) analyzed the differences between public and private organizations in terms of how they are run and concluded that the only differences were that "public organizations are more bureaucratic, and public managers are less materialistic and have weaker organizational commitment than their private sector counterparts.”

The connection between the theory and practice of QM and business excellence models has been well documented. Several studies have confirmed that excellence models constitute the essence of quality management (Ghobadian \& Woo, 1994; Hendricks \& Singhal, 1997; Tan et al., 2003) and are based on the principles and practices of successful organizations. The successful implementation of quality management has also been shown to have a positive impact on performance (see Eriksson \& Hansson, 2003; Boulter et al., 2013). Excellence models generally consist of a number of criteria that represent various important areas of an organization. Most studies of relations between different criteria in excellence models have either looked at private organizations (Samson \& Terziovski, 1999; Curkovic et al., 2000; Calvo-Mora et al., 2013; Calvo-Mora et al. 2014) or have not explained in detail the type of organizations in the data analyses; for example, see Jayamaha et al. (2009) or HerasSaizarbitoria et al. (2012).

Considering the need for contingency research (Sousa and Voss, 2002) and the lack of literature regarding the application of business excellence models in a specific sector, we aim to explore the differences between public and private organizations in the paths of business excellence models and to identify the key drivers for creating business results and customer satisfaction. This should be useful from a practical perspective. We have worked together with the Swedish Institute for Quality (SIQ), which adopted and adapted the Malcolm Baldrige National Quality Award (MBNQA) model to the local context in Sweden. The SIQ's business excellence model, as shown in Figure 1, has been used since 1992 and consists of seven main criteria and 25 subcriteria. The main criteria are leadership, information and analysis, strategic planning, human resource development, management of processes, results, and customer satisfaction. This research was conducted using the applicants' score data of all private and public organizations that applied for the Swedish quality award using the SIQ model from 1992 to 2014 ( $n=165$ ).

The remainder of this paper is organized as follows. In Section 2 we describe the theoretical basis and formulation of the research hypotheses. In Section 3 we explain the research methodology. The findings from the data analysis are presented in Section 4, before Section 5 discusses the findings in the light of the theoretical background. Section 6 concludes the paper. 


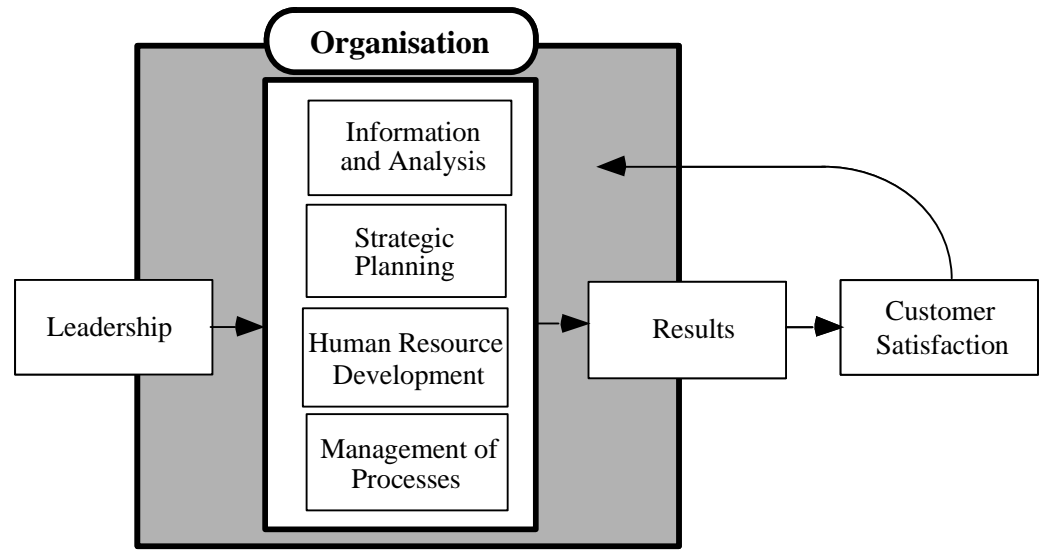

Figure 1: The SIQ business excellence model for performance excellence (SIQ, 2015)

\section{Literature review and research hypotheses}

\subsection{Validity of the Business Excellence Models}

Curkovic et al. (2000) was one of the first studies to use structural equation modeling (SEM) to investigate the validity of the paths and relationships between criteria in excellence models. They concluded that the MBNQA framework captures the concept of total quality management (TQM). Similarly, Bou-Llusar et al. (2009) studied whether the excellence models capture the essence of TQM. They studied the excellence model of the European Foundation for Quality Management (EFQM) in a survey of managers in Spanish companies and concluded that the EFQM enablers do indeed capture TQM. Furthermore, Heras-Saizarbitoria et al. (2012) found that the relationships between the criteria in the EFQM model are robust. Based on studies of business excellence models (New Zealand, Australia, and Singapore), Jayamaha et al. (2009) stated that the models are valid because they all pass the minimum requirement for measurement validity. There have also been a number of studies of how different excellence criteria relate to one another; many of these have used surveys to capture data (Samson \& Terziovski, 1999; Curkovic et al., 2000; Lee et al., 2003; Su et al., 2003; Moon et al., 2011), while some more recent studies have also used actual application scores from organizations (Heras-Saizarbitoria et al., 2012; Calvo-Mora et al., 2014).

Much important work with respect to investigating the different relationships between the criteria in excellence models has already been performed. Specifically, it is difficult to argue against the leadership effect on strategy. Research articles about excellence models have also pointed out this relationship (Jayamaha et al., 2008; Heras-Saizarbitoria et al., 2012). It is also difficult to question the positive effect of leadership on human resources. Studies of this relationship and in the context of excellence models can be seen in Gómez-Gómez et al. (2011) and Heras-Saizarbitoria et al. (2012). The leadership effect on results has been studied empirically (Moon et al., 2011). Based on a survey of South Korean organizations, Moon et al. (2011) found support for many of their hypotheses, including the leadership effect on information and analysis, strategic planning, human resource focus, and process management. Su et al.'s (2003) SEM study of Taiwanese firms and the quality award in Taiwan found that leadership is the driver of the system that creates the results. In particular, they found that leadership influences information management and that information management also impacts the other categories in the Taiwanese award model. Leadership and strategic management also influence the results in Su et al. (2003). 
Xiang et al.'s (2010) study of the Chinese quality award and analysis of the causal relationships among the criteria found that, in both Chinese service and manufacturing companies, leadership affects the other criteria in the model. Meyer and Collier (2001) used confirmatory structural equation modeling to study causal relationships in MBNQA health-care criteria. They assessed data from 220 US hospitals and, like many other manufacturing studies, found that leadership is the driver of other criteria (information and analysis, strategic planning, human resource development, process management, and organizational results). Information had a significant effect on organizational result (labeled performance), human resources had a significant effect on results, and both process management and results had a positive effect on the customer criteria.

Also, there have been many studies of excellence models and how certain criteria affect the performance and results; for example, see recent articles by Calvo-Mora et al. (2014) and Sabella et al. (2014). Calvo-Mora et al. (2014) investigated the EFQM model and stated that results are affected by the criteria of management of human resources, the strategic management of partnerships and resources, and process management. With regard to the MBNQA model, Sabella et al. (2014) argued that people management, process management, and information and analysis all affect performance. The effect of process management on results has been welldocumented (Curkovic et al., 2000; Fotopoulos \& Psomas, 2010; Calvo-Mora et al., 2014). Samson and Terziovski (1999) showed early on that that the relationship between TQM practice and organizational performance is significant and that TQM practice explains the variation in operational performance. More specifically, they stated that leadership, management of people, and a customer focus have the strongest impact on operational performance. Calvo-Mora et al. (2014) concluded that the technical factors of TQM act as a mediating variable between social TQM and results.

In summary, many articles have explained the validity and the paths between different criteria in excellence models. Most of these studies have looked at data from private organizations; for example, Samson and Terziovski (1999), Curkovic et al. (2000), Lee et al. (2003), Moon et al. (2011), and Calvo-Mora et al. (2014). However, it is difficult to argue that the business excellence models are not valid for public organizations since the models are generic in nature. Research into the use of business excellence models in public organizations generally remains limited. We found three studies on the application of business excellence models in public organizations: Eskildsen et al. (2004), Gómez-Gómez et al. (2011), and Raharjo et al. (2015). Interestingly, despite some differences between the two sectors, most of the findings of these studies do not contradict the results reported in the private organizations regarding whether the paths proposed in the excellence models are statistically significant. Therefore, there is evidence that most of the paths, as formulated in the excellence model, exist empirically (nonzero) in public organizations.

Eriksson et al. (2016, p. 14) stated that "there were surprisingly few differences in the challenges foreseen by different types of organizations.” Respondents from their Delphi study foresaw the same challenges related to quality management, regardless of whether they came from a private or a public organization. As part of our quest to find out more about the validity of excellence models for each sector, we have formulated the following two hypotheses:

Hypothesis 1: The paths in the excellence models have statistical significance for private organizations. 
Hypothesis 2: The paths in the excellence models have statistical significance for public organizations.

By having statistical significance, we mean that the existence of the path is empirically supported by the data (that is, a non-zero relationship).

\subsection{Differences between private and public organizations in business excellence models}

While several studies have reported on the differences between the private and public organizations, less attention has been devoted to how the two types of organizations differ when it comes to using business excellence models. However, a lot of important work has been presented regarding the differences between public and private organizations. An early theory of public-private distinction (Rainey et al., 1976), which is rooted in public administration, claimed that there are significant differences between the two sectors in terms of (1) their purposes, objectives, and planning; (2) their selection, management, and motivation; and (3) controlling and measuring results. Hansen and Villadsen (2010) showed that public managers in Denmark use more participative leadership, whereas private ones use more directive leadership. Along the same lines, Andersen (2010) found that public and private managers in Sweden differ significantly in terms of their leadership style and motivation profile. The public managers in his study had a more change-oriented leadership style (for example, pushing for growth, initiating new projects, offering ideas about new and different ways of doing things, giving thoughts and plans for the future), whereas the private managers had a more relationship leadership style (for example, being considerate and friendly and allowing subordinates to make decisions). Furthermore, Eskildsen et al. (2004) found that private and public organizations do not achieve excellent results in the same way. Specifically, private companies place higher emphasis on the system dimension, whereas public organizations place greater emphasis on the people dimension. Hence, the leadership effect on the other part of the organizational system (information and analysis, strategic planning, human resource development, and management of processes) should be stronger in public organizations than in their private counterparts. This is due to the fact that participatory and change-oriented leadership style is promoted in the excellence models (SIQ, 2015), and this type of leadership is generally more visible in public organizations.

Furthermore, Dixit (1997) studied the power of incentive in private versus public organizations and stated that government agencies and public enterprises are generally thought to perform poorly because the managers and workers lack high-powered incentives compared to private firms. Dixit (1997) also argued that government agencies must operate within a framework of politics. Public organizations do not generally focus on profit maximization and have to report to several stakeholders (Boland and Fowler, 2000). Using quantitative research, Boyne (2002) showed statistically that public management is characterized by more bureaucracy, a stronger desire to promote public welfare, and lower organizational commitment than private management. Lyons et al. (2006) also found that public sector employees displayed lower levels of organizational commitment than private sector employees. In the context of Swedish private and public organizations, Elg et al. (2015) stated four key arguments that distinguish private and public services: rights and access, equality, coerciveness, and legitimacy. The core values of public organizations are primarily influenced by legislation, publicity in the society, and politics, as opposed to profit-maximization in their private counterparts. Moreover, GómezGómez et al. (2011) applied partial least squares (PLS) with limited numbers of organizations, and also separated public $(n=25)$ and private organizations $(n=43)$ in their analysis. Their results showed that there are significant differences between the two groups and that 
manufacturing/private companies provide a better fit to the EFQM model than public/educational organizations. We extend this line of research using a different business excellence model (MBNQA-based) and context with more extended analyses and a larger sample size. Specifically, we consider various types of public organization, including educational organizations. Eriksson (2016) recently concluded that private organizations outperform public organizations when it comes to quality management practices, and especially with regard to process management, which appears to be easier for private firms. An earlier study by Dean and Helm (1996) also showed that private organizations are ahead of public organizations when it comes to quality management practices. Hence, due to the better fit of excellence models to private organizations, and the lack of incentives and high bureaucracy in public organizations, which makes it more difficult to generate results, we argue that the effect of the organizational system (information and analysis, strategic planning, human resource development, and management of processes) on results and customer satisfaction should be stronger in private organizations than in public ones.

Therefore, we conclude that private and public organizations are different and that differences in the paths should be evident. We summarize the differences in the following hypothesis:

Hypothesis 3: The paths of the excellence models are statistically different between private and public organizations.

Hypothesis 3a: Leadership effect on information and analysis, strategic planning, human resource development, and management of processes is positively stronger for public organizations than for private ones.

Hypothesis 3b: The effect of information and analysis, strategic planning, human resource development, and management of processes on results and customer satisfaction is positively stronger for private organizations than for public ones.

\section{Research Method}

The data were extracted from the Swedish Institute for Quality database. There were a total of 165 applicants between 1992 and 2014. For data analysis, we used the partial least squares structural equation modeling (PLS-SEM) method (Hair et al., 2012; Sarstedt et al., 2014). We chose this method because we were interested in the relationship between the independent and dependent constructs in the SIQ model, especially in terms of how well the independent constructs can predict the dependent ones. Had we been interested in testing model fit, we would have used the covariance-based structural equation modeling method (Bollen, 1989). The PLS-SEM approach also enabled us to test the paths' difference between the two groups and to identify key driver constructs for predicting endogenous constructs; in this case, business results and customer satisfaction.

We used the PLS multi-group analysis (PLS-MGA) (Henseler et al., 2009; Sarstedt et al., 2011) to compare the path coefficients between the two types of organizations, and used the importance-performance matrix analysis (IPMA) to map the key driver constructs' total effects (importance) and average scores (performance) on a target construct (see Rigdon et al., 2011; Hair et al., 2014; Schloderer et al., 2014). The software SmartPLS version 3.2.1 was used for model estimation (Ringle et al., 2015).

We used reflective measurement for the PLS model because the measure variables (sub-criteria) 
are supposedly affected by the same underlying latent variable (main criteria). In other words, the main criteria - such as leadership, which is a theoretical concept - are measured by a number of aspects. Furthermore, the measure variables are highly correlated and internally consistent among themselves (Chin, 1998). Note that incorrect choice of measurement model may lead to deflation or inflation of the path coefficients and the R-square values (Roy et al., 2012).

The applicants' scores data in all sub-criteria are provided by an impartial group of examiners who are trained by SIQ. These scores data are in the form of percentages. Considering the fact that the sub-criteria and their weights have been re-organized several times over the years, we transformed those scores (i.e. percentages) into points before conducting further analyses. For example, the main criterion 'leadership', out of 1000 points, had a weighting of 90 points from 1992-1998, 120 points from 1999-2003, and 150 points from 2004-2014. Suppose that an organization receives 50\% in 1992 and 50\% again in 2014, then their transformed values in the form of points, which are 45 points (50\% of 90 ) and 75 points (50\% of 150$)$, respectively, are used for the data analysis. The maximum point that each applicant can have (that is, 1000 points) and the seven main criteria have remained the same for all years.

The latest configurations for point allocation to the sub-criteria are provided in Table 1 . The three following mergers were used for the sub-criteria:

- Sub-criterion 1.3 ('leadership for processes') is merged with sub-criterion 1.2 ('leadership for continuous improvement') and coded as 'L2_3' because 'leadership for processes’ only existed from 2004.

- Sub-criterion 4.3 ('employee involvement and participation') is merged with subcriterion 4.6 ('results - employee involvement and development') and coded as 'HRD3_6' because sub-criterion 4.6 only existed from 1996.

- Sub-criteria 5.1 ('control of processes') and 5.2 ('improvement of processes') are combined, coded as 'MP1_2', for two reasons: (a) they existed from 2004; and (b) they were measured by other dimensions before 2004, such as 'main processes', 'supporting processes', and 'development of processes, goods and services'.

Table 1. SIQ main and sub-criteria (SIQ, 2015)

\begin{tabular}{|c|c|c|c|}
\hline Main criteria & Sub-criteria & Points & Code \\
\hline \multirow{5}{*}{$\begin{array}{l}\text { Leadership } \\
\text { (150 points) }\end{array}$} & 1.1 Top management & 45 & L1 \\
\hline & 1.2 Leadership for continuous improvement & 30 & L2_3 \\
\hline & 1.3 Leadership for processes & 30 & L2_3 \\
\hline & 1.4 Community involvement & 15 & L4 \\
\hline & 1.5 Environmental management & 30 & L5 \\
\hline \multirow{2}{*}{$\begin{array}{l}\text { Information and } \\
\text { analysis } \\
\text { (70 points) }\end{array}$} & 2.1 Management and use of information & 45 & IA1 \\
\hline & $\begin{array}{l}2.2 \text { Information on leading organizations and } \\
\text { competitors }\end{array}$ & 25 & IA2 \\
\hline $\begin{array}{l}\text { Strategic planning } \\
\text { (50 points) }\end{array}$ & 3.1 Organizational planning & 50 & SP1 \\
\hline \multirow{5}{*}{$\begin{array}{l}\text { Human resource } \\
\text { development } \\
\text { (150 points) }\end{array}$} & 4.1 Strategic competence development & 25 & HRD1 \\
\hline & 4.2 Individual competence development & 25 & HRD2 \\
\hline & 4.3 Employee involvement and participation & 35 & HRD3_6 \\
\hline & 4.4 Recognition and encouragement & 20 & HRD4 \\
\hline & 4.5 Work environment and job satisfaction & 20 & HRD5 \\
\hline
\end{tabular}




\begin{tabular}{lrlrr}
\hline & 4.6 & $\begin{array}{l}\text { Results - employee involvement and } \\
\text { development }\end{array}$ & 25 & HRD3_6 \\
\hline $\begin{array}{l}\text { Management of } \\
\text { processes } \\
\text { (120 points) }\end{array}$ & 5.1 & Control of processes & 60 & MP1_2 \\
& 5.2 & Improvement of processes & 40 & MP1_2 \\
& 5.3 & Collaboration with suppliers and partners & 20 & MP3 \\
Results & 6.1 & Results - processes & 100 & R1 \\
$(160$ points $)$ & 6.2 & Results - collaboration with suppliers and & 20 & R2 \\
& & partners & 40 & R3 \\
& 6.3 & Results - community involvement and & & \\
\hline & & environmental management & 50 & CS1 \\
Customer satisfaction & 7.1 & Customer expectations & 45 & CS2 \\
(300 points) & 7.2 & Collaboration with customers & Commitments to customers & CS3 \\
& 7.4 & Measurement of customer satisfaction & 60 & CS4 \\
& 7.5 & Results - customer satisfaction & CS5 \\
\hline
\end{tabular}

The SIQ model has, in fact, not been tested for measurement validity before. We therefore start our data analysis with testing its measurement validity using the entire dataset assuming that the general model can be applied for both private and public, virtually all, organizations in Sweden.

\section{Results}

\subsection{Current SIQ model assessment}

The current configuration of SIQ model was assessed using all data $(n=165)$. Unfortunately, it did not meet the discriminant validity for both Fornell-Larcker and heterotrait-monotrait (HTMT) criteria (Henseler et al., 2015). In particular, the HTMT-inference - the most liberal criterion, with 5000 samples (significance level=0.05) - was used considering the close relationships among the constructs and indicators.

Table 2 shows the discriminant validity assessment results using Fornell-Larcker criteria. It can be seen that the 'human resource development' construct is highly correlated with 'customer satisfaction' (0.852). This correlation should fall below the square root of the average variance extracted (AVE) value, which is on the diagonal (0.841). Table 3 shows the HTMT results sorted by the bias-corrected upper confidence limit. The upper confidence limit values of the HTMT ratio for the first two construct relationships (Info\&Analysis $\rightarrow$ Customer Satisfaction and Results $\rightarrow$ Leadership) are above 1 , indicating lack of discriminant validity.

Table 2. Discriminant validity of current configuration (Fornell-Larcker) 


\begin{tabular}{|c|c|c|c|c|c|c|c|}
\hline $\begin{array}{l}\text { Fornell-Larcker } \\
\text { criterion }^{1}\end{array}$ & $\begin{array}{l}\text { Customer } \\
\text { Satisfaction }\end{array}$ & $\begin{array}{c}\text { HumanRes } \\
\text { Dev. }\end{array}$ & $\begin{array}{c}\text { Info\& } \\
\text { Analysis }\end{array}$ & Leadership & $\begin{array}{l}\text { Mgmt of } \\
\text { Processes }\end{array}$ & Results & $\begin{array}{l}\text { Strategic } \\
\text { Planning }\end{array}$ \\
\hline Customer Satisfaction & 0.841 & & & & & & \\
\hline HumanResDev. & 0.852 & 0.881 & & & & & \\
\hline Info\&Analysis & 0.828 & 0.784 & 0.931 & & & & \\
\hline Leadership & 0.782 & 0.820 & 0.784 & 0.815 & & & \\
\hline Mgmt of Processes & 0.731 & 0.707 & 0.710 & 0.687 & 0.917 & & \\
\hline Results & 0.766 & 0.757 & 0.678 & 0.764 & 0.670 & 0.851 & \\
\hline Strategic Planning & 0.770 & 0.774 & 0.755 & 0.740 & 0.775 & 0.627 & 1 \\
\hline
\end{tabular}

${ }^{1)}$ Note that the diagonal entries (i.e. square-root of average variance extracted) should be higher than the off-diagonal entries (i.e. correlation between the constructs)

Table 3. Discriminant validity of current configuration (HTMT-inference)

\begin{tabular}{lccccc}
\hline HTMT (CI-bias corrected bootstrap) & $\begin{array}{c}\text { Original } \\
\text { Sample (O) }\end{array}$ & $\begin{array}{c}\text { Sample } \\
\text { Mean (M) }\end{array}$ & Bias & $2.50 \%$ & $97.50 \%$ \\
\hline Info\&Analysis -> CustomerSatisf. & 0.951 & 0.951 & 0 & 0.893 & 1.011 \\
Results -> Leadership & 0.931 & 0.931 & 0 & 0.857 & 1.004 \\
Leadership -> Info\&Analysis & 0.922 & 0.922 & 0 & 0.86 & 0.983 \\
HumanResDev. -> CustomerSatisf. & 0.93 & 0.93 & -0.001 & 0.888 & 0.966 \\
Leadership -> HumanResDev. & 0.908 & 0.907 & -0.001 & 0.855 & 0.954 \\
Leadership -> CustomerSatisf. & 0.883 & 0.882 & -0.001 & 0.814 & 0.944 \\
Results -> CustomerSatisf. & 0.876 & 0.876 & 0.001 & 0.811 & 0.943 \\
Info\&Analysis -> HumanResDev. & 0.885 & 0.884 & 0 & 0.827 & 0.942 \\
MgmtOfProcesses -> Info\&Analysis & 0.854 & 0.856 & 0.001 & 0.769 & 0.941 \\
Results -> MgmtOfProcesses & 0.828 & 0.831 & 0.002 & 0.729 & 0.94 \\
MgmtOfProcesses -> CustomerSatisf. & 0.859 & 0.86 & 0.001 & 0.785 & 0.934 \\
Results -> HumanResDev. & 0.859 & 0.86 & 0 & 0.786 & 0.931 \\
StrategicPlanning -> MgmtOfProcesses & 0.858 & 0.858 & 0 & 0.791 & 0.923 \\
MgmtOfProcesses -> Leadership & 0.823 & 0.822 & 0 & 0.731 & 0.911 \\
Results -> Info\&Analysis & 0.808 & 0.811 & 0.003 & 0.73 & 0.897 \\
MgmtOfProcesses -> HumanResDev. & 0.817 & 0.817 & 0 & 0.736 & 0.895 \\
StrategicPlanning -> Info\&Analysis & 0.821 & 0.821 & 0 & 0.75 & 0.889 \\
StrategicPlanning -> CustomerSatisf. & 0.817 & 0.817 & 0 & 0.761 & 0.87 \\
StrategicPlanning -> HumanResDev. & 0.806 & 0.806 & 0 & 0.75 & 0.86 \\
StrategicPlanning -> Leadership & 0.796 & 0.795 & 0 & 0.727 & 0.859 \\
StrategicPlanning -> Results & 0.692 & 0.694 & 0.002 & 0.606 & 0.789 \\
\hline
\end{tabular}

A rearrangement was conducted based on the problematic indicators' correlation matrix (see Figure 2) and their contents, as described in the SIQ model manual. All the constructs and their relationships remained the same. Three indicators were found to be problematic and were moved to other constructs. 


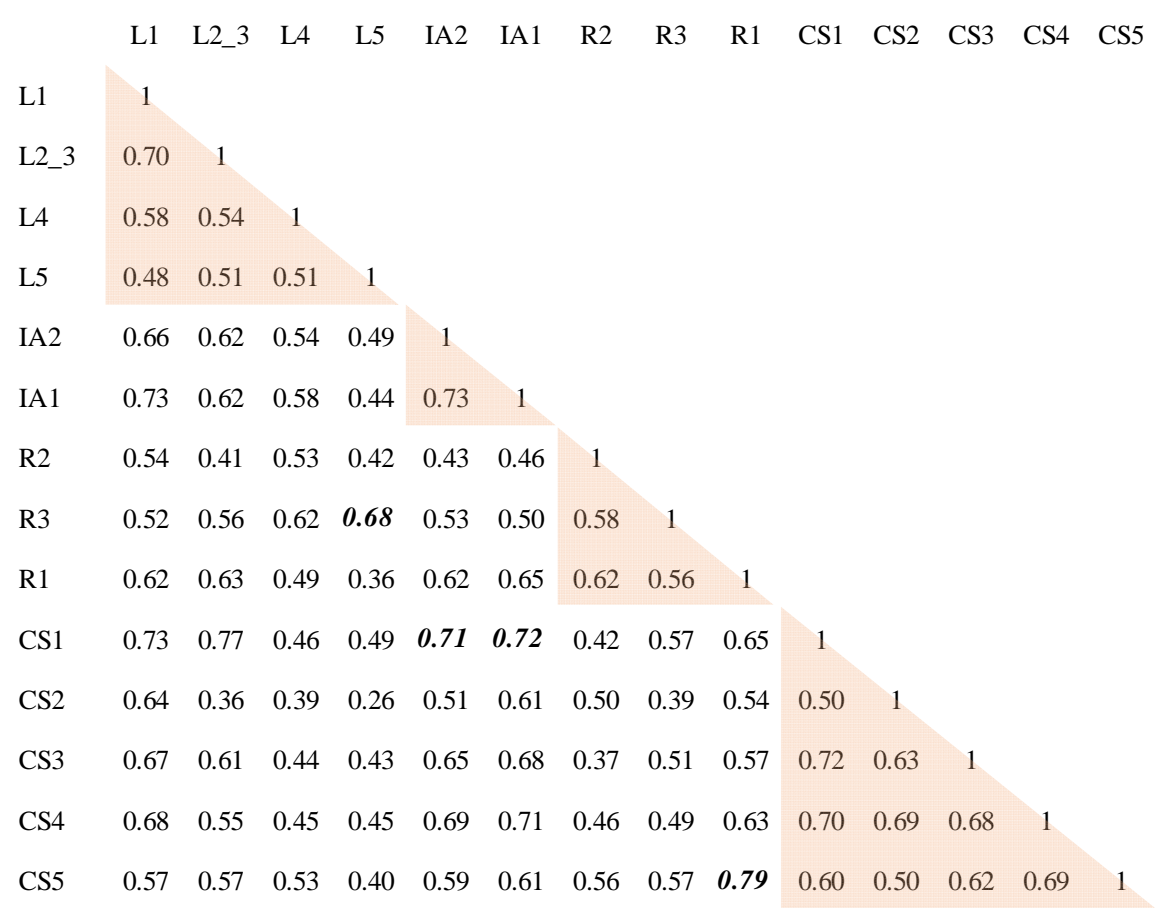

Figure 2. Correlations among problematic indicators (shaded areas represent correlations within the same construct)

- Sub-criterion 7.5 ('results - customer satisfaction', coded as CS5) was moved under 'results' because it is more correlated to the sub-criteria in 'results' than to the subcriteria in 'customer satisfaction' itself. This move can also be justified by considering the fact that CS5 also only deals with results. Specifically, the correlation between CS5 and R1 is as high as 0.79 (italicized in Figure 2).

- Sub-criterion 7.1 ('customer expectations', CS1) was moved under 'information and analysis'. It has correlation values higher than 0.7 with the indicators under 'information and analysis' (IA1 and IA2). As described in the SIQ model manual, CS1 deals with how the organization collects information about current and future customers and their needs and expectations. This is closely related to 'information and analysis', which deals with how such information is managed.

- Sub-criterion 6.3 ('results - community involvement and environmental management', R3) was moved to 'leadership'. It has a higher correlation value with sub-criterion 1.5 ('environmental management', L5) than with other sub-criteria under 'results'. This move can be justified on the basis that the two criteria concern the same subject.

\subsection{Revised SIQ model}

Figure 3 shows the final model after the three rearrangements. We refer to this figure as the 'revised SIQ model' and use this term for the remainder of the analysis. Note that the feedback loop, which indicates a non-recursive relationship (see Figure 1), has been removed because it does not represent a cause-and-effect relationship. This removal was confirmed by interviewing SIQ staff who know the historical idea of the model. The discriminant validity assessment results of the revised SIQ model are provided in Tables 4 and 5, which are set out in the same way as Tables 2 and 3. Now there does not appear to be any problem with the discriminant validity for both Fornell-Larcker and HTMT-inference criteria. The convergent validity (all AVE values are above 0.5 ) and internal consistency reliability criteria (Cronbach's alpha and 
rho-c values are above 0.7 ) are met.

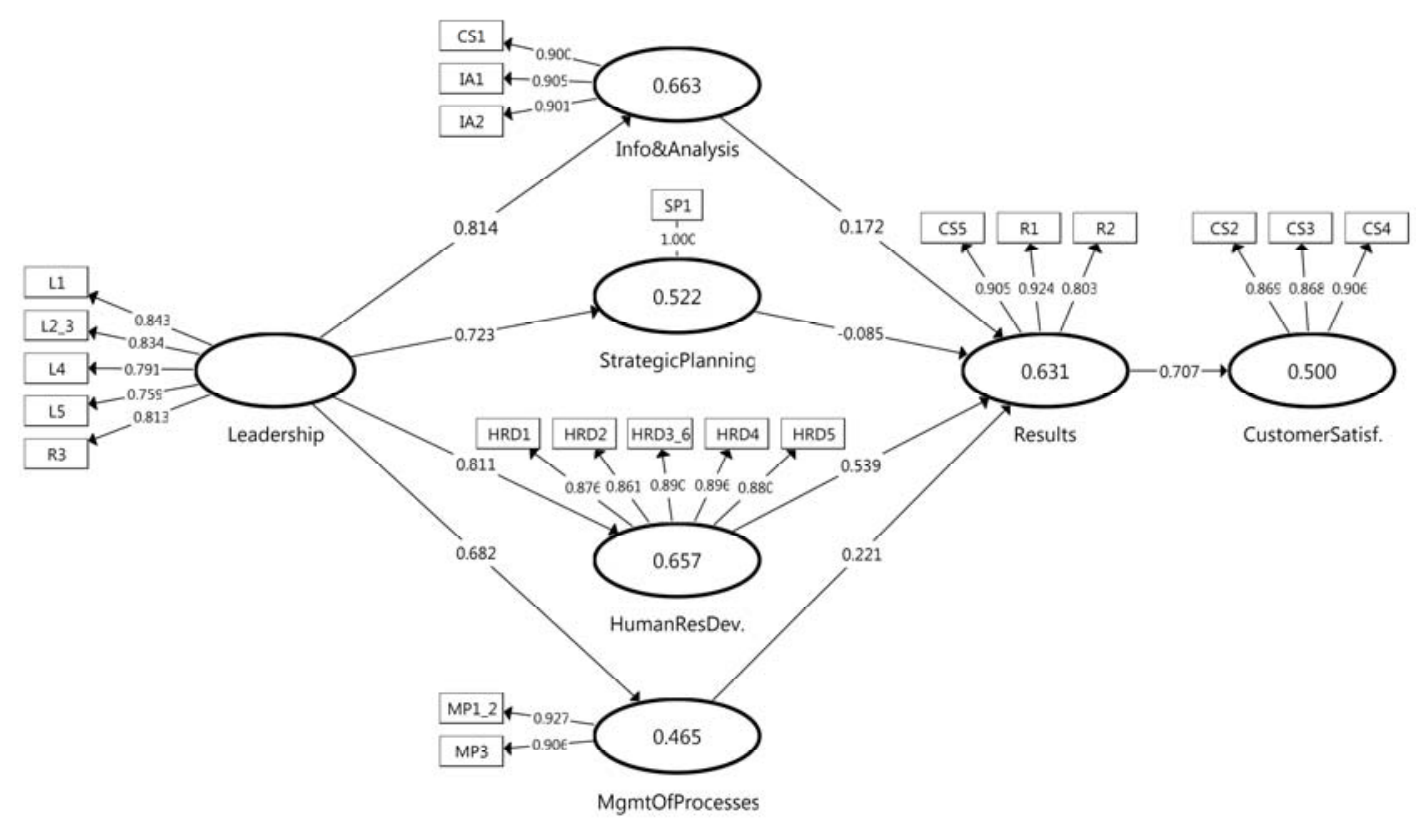

Figure 3. The revised SIQ model

Table 4. Discriminant validity of revised SIQ model (Fornell-Larcker)

\begin{tabular}{|c|c|c|c|c|c|c|c|}
\hline $\begin{array}{l}\text { Fornell-Larcker } \\
\text { criterion }^{1}\end{array}$ & $\begin{array}{c}\text { Customer } \\
\text { Satisfaction }\end{array}$ & $\begin{array}{c}\text { HumanRes } \\
\text { Dev. }\end{array}$ & $\begin{array}{c}\text { Info\& } \\
\text { Analysis }\end{array}$ & Leadership & $\begin{array}{l}\text { Mgmt of } \\
\text { Processes }\end{array}$ & Results & $\begin{array}{l}\text { Strategic } \\
\text { Planning }\end{array}$ \\
\hline Customer Satisfaction & 0.881 & & & & & & \\
\hline HumanResDev. & 0.794 & 0.881 & & & & & \\
\hline Info\&Analysis & 0.809 & 0.828 & 0.902 & & & & \\
\hline Leadership & 0.707 & 0.811 & 0.814 & 0.809 & & & \\
\hline Mgmt of Processes & 0.738 & 0.708 & 0.713 & 0.682 & 0.917 & & \\
\hline Results & 0.707 & 0.773 & 0.711 & 0.736 & 0.66 & 0.879 & \\
\hline Strategic Planning & 0.764 & 0.774 & 0.765 & 0.723 & 0.776 & 0.635 & 1 \\
\hline
\end{tabular}

Table 5. Discriminant validity of revised SIQ model (HTMT-inference) 


\begin{tabular}{|c|c|c|c|c|c|}
\hline HTMT (CI-bias corrected bootstrap) & $\begin{array}{c}\text { Original } \\
\text { Sample }(O)\end{array}$ & $\begin{array}{c}\text { Sample } \\
\text { Mean (M) }\end{array}$ & Bias & $2.50 \%$ & $97.50 \%$ \\
\hline Info\&Analysis -> CustomerSatisf. & 0.925 & 0.925 & 0 & 0.876 & 0.974 \\
\hline MgmtOfProcesses -> CustomerSatisf. & 0.879 & 0.88 & 0.001 & 0.798 & 0.961 \\
\hline Leadership -> Info\&Analysis & 0.91 & 0.91 & 0 & 0.864 & 0.957 \\
\hline Info\&Analysis -> HumanResDev. & 0.911 & 0.911 & 0 & 0.868 & 0.950 \\
\hline HumanResDev. -> CustomerSatisf. & 0.888 & 0.889 & 0 & 0.833 & 0.945 \\
\hline StrategicPlanning -> MgmtOfProcesses & 0.858 & 0.859 & 0.001 & 0.794 & 0.926 \\
\hline Results -> HumanResDev. & 0.863 & 0.862 & -0.001 & 0.796 & 0.925 \\
\hline Leadership -> HumanResDev. & 0.875 & 0.875 & 0 & 0.822 & 0.924 \\
\hline MgmtOfProcesses -> Info\&Analysis & 0.837 & 0.839 & 0.002 & 0.765 & 0.915 \\
\hline Results -> Leadership & 0.848 & 0.847 & -0.002 & 0.773 & 0.912 \\
\hline Results -> CustomerSatisf. & 0.819 & 0.82 & 0.001 & 0.730 & 0.910 \\
\hline Results -> MgmtOfProcesses & 0.799 & 0.8 & 0.001 & 0.698 & 0.905 \\
\hline MgmtOfProcesses -> HumanResDev. & 0.817 & 0.817 & 0 & 0.733 & 0.896 \\
\hline MgmtOfProcesses -> Leadership & 0.798 & 0.798 & 0 & 0.706 & 0.888 \\
\hline Results -> Info\&Analysis & 0.811 & 0.811 & 0 & 0.734 & 0.885 \\
\hline StrategicPlanning -> CustomerSatisf. & 0.823 & 0.823 & 0 & 0.759 & 0.883 \\
\hline Leadership -> CustomerSatisf. & 0.794 & 0.794 & 0 & 0.708 & 0.877 \\
\hline StrategicPlanning -> Info\&Analysis & 0.813 & 0.813 & 0 & 0.750 & 0.870 \\
\hline StrategicPlanning -> HumanResDev. & 0.806 & 0.806 & 0 & 0.748 & 0.858 \\
\hline StrategicPlanning -> Leadership & 0.757 & 0.757 & -0.001 & 0.685 & 0.825 \\
\hline StrategicPlanning -> Results & 0.688 & 0.688 & 0 & 0.597 & 0.775 \\
\hline
\end{tabular}

\subsection{Descriptive statistics of revised SIQ model}

The descriptive statistics of the main criteria and sub-criteria are given in Table 6 and Table 7, respectively. The values for the main criteria are obtained from the total of the sub-criteria based on the revised model (Figure 3). For readers interested in the statistical differences between the scores in private and public organizations' main criteria, we refer to the study by Eriksson (2016).

Table 6. Descriptive statistics for applicants score in the main criteria (revised model)

\begin{tabular}{lcccccccccc}
\hline \multirow{2}{*}{ Main criteria } & \multicolumn{2}{c}{ Mean } & \multicolumn{2}{c}{ Median } & \multicolumn{2}{c}{ Stdev } & \multicolumn{2}{c}{ Min } & \multicolumn{3}{c}{ Max } \\
& Private & Public & Private & Public & Private & Public & Private & Public & Private & Public \\
\hline Leadership & 58.7 & 62.3 & 55.5 & 58.4 & 24.2 & 29.7 & 9.0 & 8.5 & 122.8 & 133.8 \\
Info\&Analysis & 48.2 & 48.0 & 46.2 & 46.3 & 18.1 & 20.7 & 12.8 & 9.5 & 91.0 & 97.0 \\
StrategicPlanning & 26.2 & 24.6 & 25.5 & 25.1 & 9.8 & 9.4 & 6.0 & 7.2 & 52.8 & 41.4 \\
HumanResDev. & 58.3 & 57.6 & 56.3 & 55.0 & 21.3 & 23.0 & 11.5 & 11.3 & 107.3 & 121.5 \\
MgmtOfProcess & 54.2 & 43.8 & 51.5 & 42.3 & 20.5 & 20.0 & 17.0 & 10.6 & 101.6 & 98.0 \\
Results & 60.2 & 60.4 & 53.0 & 46.6 & 36.4 & 41.0 & 4.5 & 0.0 & 157.0 & 176.0 \\
CustomerSatisf. & 59.1 & 54.4 & 57.5 & 54.9 & 20.4 & 22.5 & 17.0 & 11.5 & 110.0 & 106.3 \\
\hline \multirow{2}{*}{ N(p. } & & & & & & & & & &
\end{tabular}

* $\mathrm{N}$ (private $)=93 ; \mathrm{N}$ (public $)=72$ 
Table 7. Descriptive statistics for applicants score in the sub-criteria

\begin{tabular}{|c|c|c|c|c|c|c|c|c|c|c|}
\hline \multirow{2}{*}{ Sub-criteria } & \multicolumn{2}{|c|}{ Mean } & \multicolumn{2}{|c|}{ Median } & \multicolumn{2}{|c|}{ Stdev } & \multicolumn{2}{|c|}{ Min } & \multicolumn{2}{|c|}{ Max } \\
\hline & Private & Public & Private & Public & Private & Public & Private & Public & Private & Public \\
\hline L1 & 22.0 & 21.7 & 22.5 & 22.5 & 7.1 & 7.8 & 4.5 & 4.5 & 38.3 & 40.5 \\
\hline L2_3 & 15.2 & 18.2 & 12.5 & 15.0 & 9.2 & 11.8 & 2.5 & 2.0 & 45.0 & 55.5 \\
\hline L4 & 4.8 & 4.4 & 4.5 & 3.8 & 2.8 & 2.5 & 0.0 & 0.0 & 12.0 & 10.5 \\
\hline L5 & 10.9 & 11.9 & 10.5 & 12.0 & 5.9 & 6.3 & 0.0 & 0.0 & 26.3 & 24.0 \\
\hline IA2 & 8.1 & 8.3 & 7.5 & 7.5 & 4.0 & 4.5 & 0.0 & 0.0 & 17.5 & 17.5 \\
\hline IA1 & 20.6 & 19.4 & 20.3 & 18.0 & 7.9 & 8.5 & 5.0 & 3.0 & 40.5 & 39.1 \\
\hline SP1 & 26.2 & 24.6 & 25.5 & 25.1 & 9.8 & 9.4 & 6.0 & 7.2 & 52.8 & 41.4 \\
\hline HRD1 & 10.5 & 10.0 & 10.0 & 10.0 & 4.3 & 4.3 & 0.0 & 2.0 & 19.5 & 18.8 \\
\hline HRD2 & 12.5 & 11.6 & 12.5 & 11.4 & 4.3 & 4.0 & 2.5 & 3.8 & 26.0 & 22.5 \\
\hline HRD3_6 & 19.2 & 20.6 & 18.3 & 18.4 & 8.7 & 9.9 & 2.0 & 2.0 & 42.3 & 50.8 \\
\hline HRD4 & 7.2 & 6.8 & 7.0 & 6.6 & 3.6 & 3.8 & 0.0 & 0.0 & 16.3 & 18.0 \\
\hline HRD5 & 9.0 & 8.6 & 9.0 & 8.4 & 3.4 & 3.3 & 2.0 & 0.0 & 17.8 & 16.0 \\
\hline MP3 & 7.6 & 5.8 & 7.0 & 6.0 & 3.5 & 3.1 & 0.0 & 0.0 & 15.0 & 16.0 \\
\hline MP1_2 & 46.6 & 38.0 & 45.0 & 36.0 & 18.2 & 17.6 & 10.0 & 10.6 & 87.6 & 82.0 \\
\hline $\mathrm{R} 2$ & 3.0 & 2.3 & 2.0 & 2.0 & 3.4 & 2.8 & 0.0 & 0.0 & 15.5 & 12.0 \\
\hline R3 & 5.9 & 6.2 & 4.0 & 4.0 & 5.5 & 6.4 & 0.0 & 0.0 & 20.0 & 26.0 \\
\hline $\mathrm{R} 1$ & 25.1 & 25.2 & 22.5 & 20.0 & 15.9 & 18.1 & 0.0 & 0.0 & 70.0 & 75.0 \\
\hline CS1 & 19.5 & 20.3 & 17.5 & 18.2 & 7.9 & 9.9 & 5.3 & 2.8 & 40.0 & 42.5 \\
\hline CS2 & 25.3 & 21.7 & 24.0 & 21.6 & 8.5 & 8.3 & 9.6 & 6.0 & 48.0 & 40.5 \\
\hline CS3 & 10.0 & 8.4 & 10.0 & 7.5 & 4.4 & 4.6 & 1.5 & 0.0 & 20.0 & 20.0 \\
\hline CS4 & 23.8 & 24.3 & 24.0 & 24.0 & 10.5 & 11.5 & 0.0 & 0.0 & 51.0 & 49.8 \\
\hline CS5 & 32.1 & 32.9 & 30.0 & 28.2 & 20.9 & 22.5 & 0.0 & 0.0 & 90.0 & 90.0 \\
\hline
\end{tabular}

$* \mathrm{~N}($ private $)=93 ; \mathrm{N}($ public $)=72$

\subsection{Scores over time}

The mean values of the main criteria scores over time, from 1992 to 2014, are shown in Figure 4. As in the previous section, the values for the main criteria for each applicant are obtained from the total of the sub-criteria following the revised model (Figure 3). It appears that the trends for all main criteria do not differ markedly over time. The linkages among the main criteria, namely, the paths in the SIQ model are therefore likely to remain stable over time. 


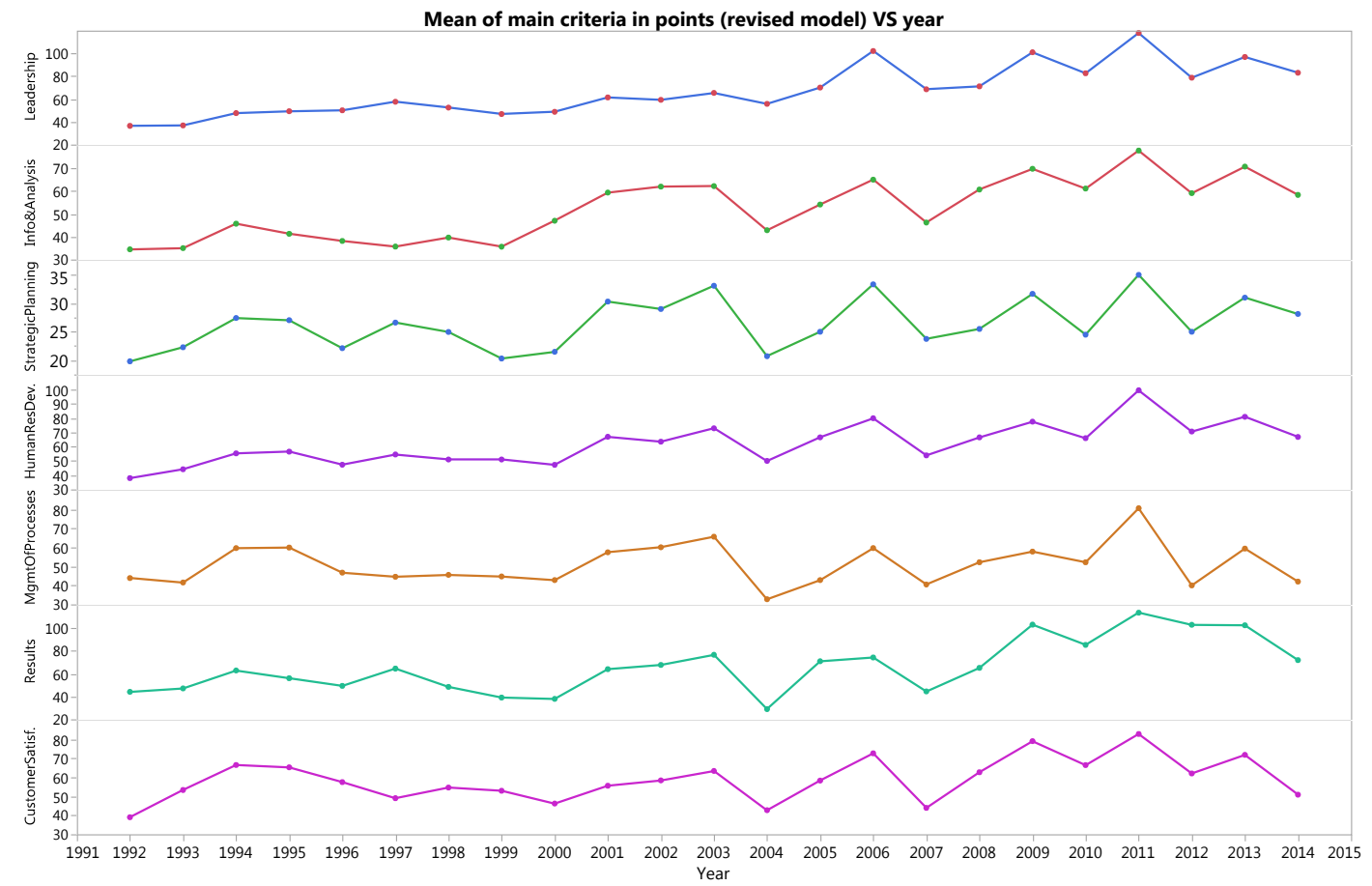

Figure 4. Trends of main criteria scores over time

\subsection{Comparing private and public organizations}

The PLS algorithm (implemented in SmartPLS software) was used for estimating the loadings of each construct. A bias-corrected bootstrap with 5000 samples (significance level=0.05) was conducted to test the statistical significance of the paths in both private and public organizations. The results are shown in Table 8. For the measurement model, all loadings are significant and greater than 0.707 . For the structural model, most of the paths are statistically significant. In other words, we have found - with the exception of three paths - strong evidence to support Hypotheses 1 and 2. Those three paths are as follows:

Table 8. The path coefficients of revised SIQ model 


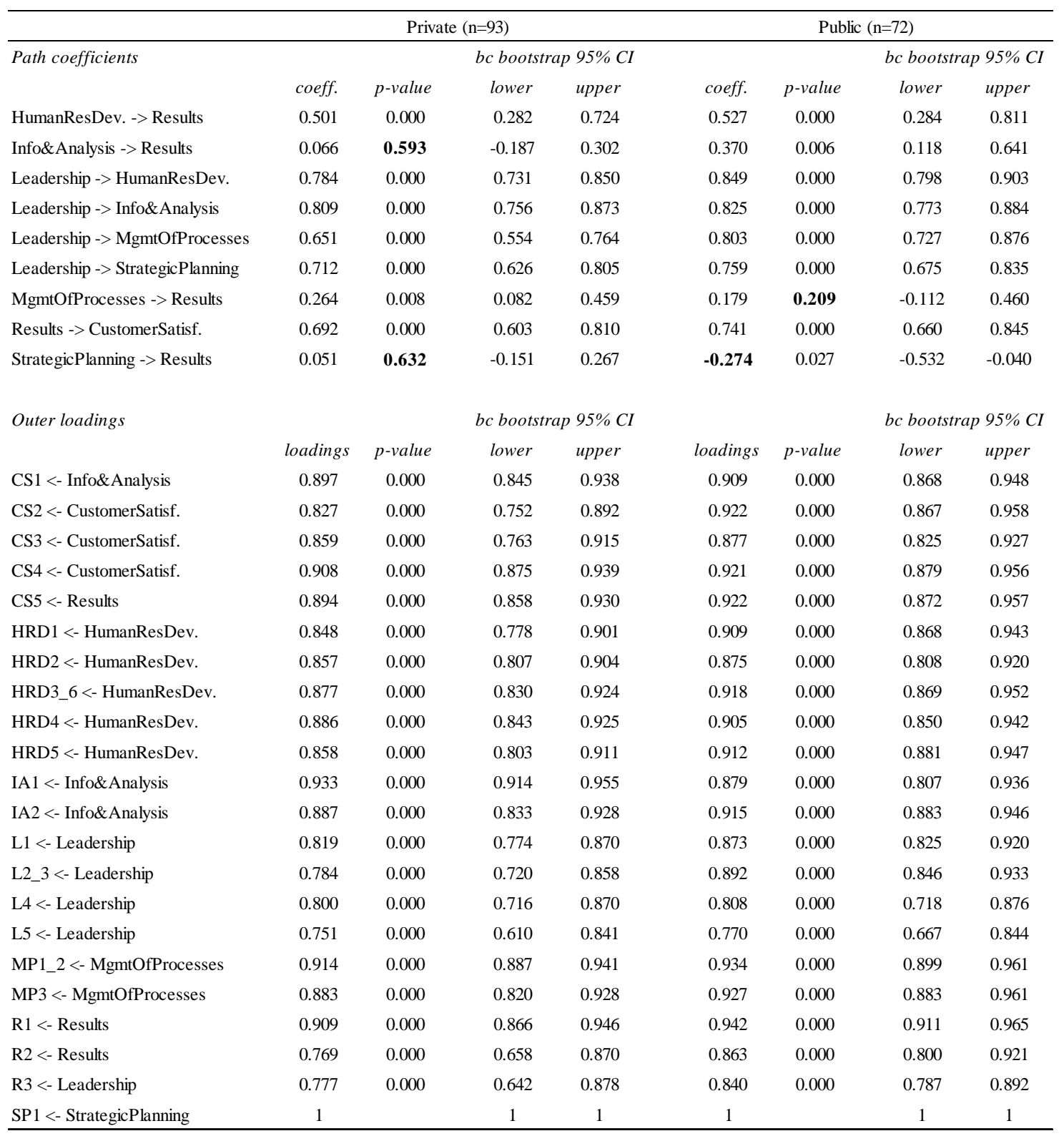

- The path from ‘information and analysis' to 'results' (Info\&Analysis $\rightarrow$ Results) in private organizations is not statistically different from zero, based on the sample. This means that we do not have sufficient evidence to substantiate the effect of 'information and analysis' on 'results' in private organizations.

- The path from 'strategic planning' to 'results' is not statistically significant in private organizations, but it is in public organizations with a negative coefficient. This is rather surprising since the zero-order correlation between the two constructs is positive. Nevertheless, the negative coefficient should be interpreted because it reflects the effect of 'strategic planning' on 'results' after other predictor constructs are held constant or controlled for.

- The path from 'management of processes' to 'results' (MgmtOfProcesses $\rightarrow$ Results) in public organizations is not significantly different from zero (not statistically significant).

The model assessment results are shown in Table 9. The $\mathrm{R}^{2}$ adjusted (R-sq adj) is used to consider the different sample size between private and public organizations. In general, the 
endogenous constructs in public organization have higher R-sq adjusted values than those of private organizations, except for 'results' (0.625 versus 0.634$)$. This implies that the variation inherent in the constructs in private organizations is more difficult to explain. The convergent validity (all AVE values are above 0.5 ) and internal consistency reliability criteria (Cronbach's alpha and rho-c values are above 0.7 ) are met for both organizations.

To assess the predictive relevance, we conducted blindfolding to obtain cross-validated redundancy measures for each endogenous construct with omission distance of $7(D=7)$. The resulting $\mathrm{Q}^{2}$ values of blindfolding are shown in the last column of Table 9. The fact that all $\mathrm{Q}^{2}$ values are greater than zero means that all of the independent constructs have predictive relevance for the dependent constructs (Hair et al., 2014). For example, 'leadership' has predictive relevance for 'human resource development'.

Table 9. Model assessment of revised SIQ model

\begin{tabular}{lccccc}
\hline & rho-c & $\begin{array}{c}\text { Cronbachs } \\
\text { alpha }\end{array}$ & AVE & R-sq adj & Q-sq (D=7) \\
\cline { 2 - 6 } Private (n=93) & & & & & \\
CustomerSatisf. & 0.899 & 0.833 & 0.749 & 0.473 & 0.344 \\
HumanResDev. & 0.937 & 0.916 & 0.749 & 0.611 & 0.448 \\
Info\&Analysis & 0.932 & 0.891 & 0.821 & 0.651 & 0.532 \\
Leadership & 0.890 & 0.848 & 0.619 & NA & NA \\
MgmtOfProcesses & 0.893 & 0.763 & 0.807 & 0.417 & 0.330 \\
Results & 0.894 & 0.822 & 0.739 & 0.634 & 0.455 \\
StrategicPlanning & 1.000 & 1.000 & 1.000 & 0.501 & 0.491 \\
& & & & & \\
Public (n=72) & & & & & \\
CustomerSatisf. & 0.933 & 0.892 & 0.822 & 0.543 & 0.444 \\
HumanResDev. & 0.957 & 0.944 & 0.817 & 0.717 & 0.585 \\
Info\&Analysis & 0.928 & 0.885 & 0.812 & 0.676 & 0.551 \\
Leadership & 0.922 & 0.894 & 0.702 & NA & NA \\
MgmtOfProcesses & 0.928 & 0.845 & 0.866 & 0.639 & 0.549 \\
Results & 0.935 & 0.895 & 0.828 & 0.625 & 0.516 \\
StrategicPlanning & 1.000 & 1.000 & 1.000 & 0.570 & 0.560 \\
\hline
\end{tabular}

We also analyzed the effect size values $\left(\mathrm{f}^{2}\right)$, with results shown in Figure 5 . The effect size, $\mathrm{f}^{2}$ (f-square), values show the contribution of an exogenous construct (such as leadership) towards the $\mathrm{R}^{2}$ of an endogenous construct (such as strategic planning). Hair et al. (2014) recommended that the $\mathrm{f}^{2}$ values of $0.35,0.15$, and 0.02 should be large, medium, and small, respectively. Certain observations are worth highlighting here.

- Confirming the R-sq adjusted results (Table 9), the effect size values of the constructs in public organizations are generally higher than those in private organizations.

- The contribution of 'leadership' towards the $\mathrm{R}^{2}$ of its direct effects (human resource development, information and analysis, management of processes, strategic planning) is strong, and much higher than the cut-off value of 0.35 (Hair et al., 2014). 'Results' made a similar contribution to the $\mathrm{R}^{2}$ of 'customer satisfaction'.

- The contribution of 'human resource development' towards the $\mathrm{R}^{2}$ of 'results' is at the medium level for both types of organizations. 
- The contribution of 'information and analysis', 'management of processes', and 'strategic planning' towards explaining the variation in 'results' is relatively small.

Figure 6 provides the path diagrams for both private and public organizations. The italicized numbers represent the paths' coefficients for public organizations. The effect of 'leadership' on its direct subsequent constructs can generally be seen to be very strong. More specifically, the path from 'leadership' $\rightarrow$ 'human resource development' $\rightarrow$ 'results' is strong for both private and public organizations.

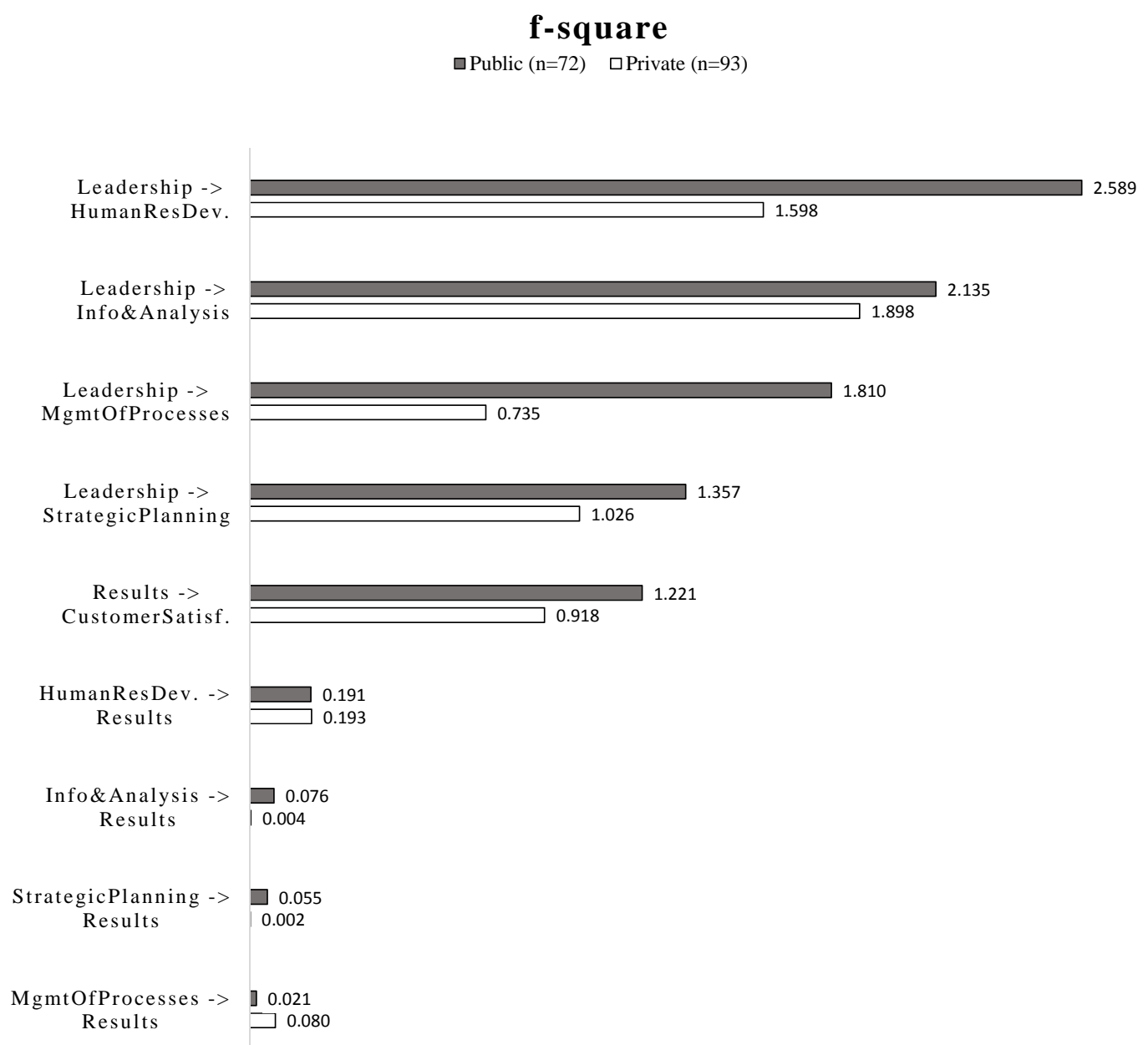

Figure 5. The f-square values 


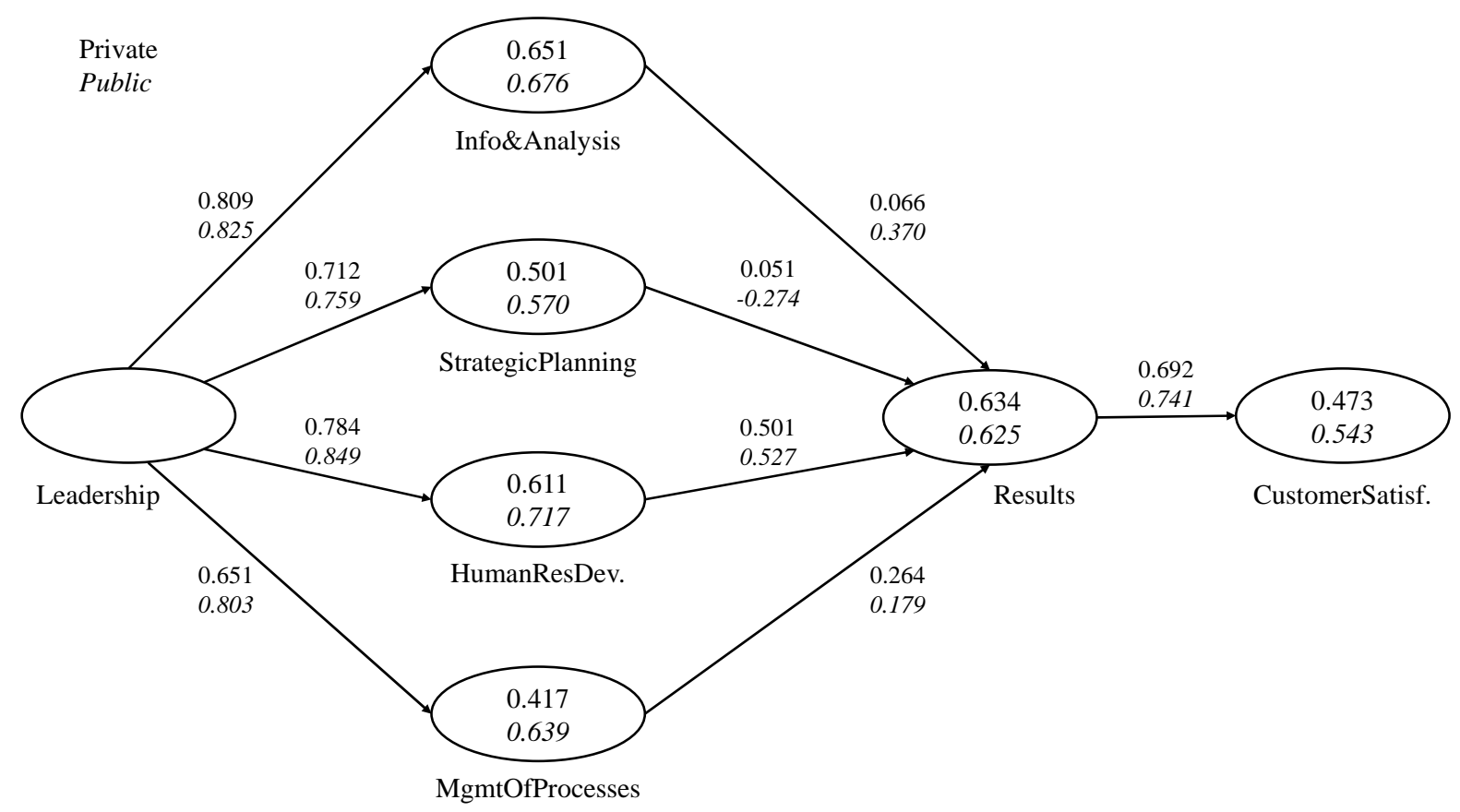

Figure 6. Path diagram with R-sq adjusted on the constructs

The PLS-MGA results for comparing private and public organization path coefficients are shown in Table 10. Note that the PLS-MGA method (Henseler et al., 2009) uses a bootstrapping procedure and the reported $p$-value is the percentage of the bootstrapped comparisons between the two groups that meets a certain criterion (for example, Group $1>$ Group 2). Therefore, a percentage smaller than 0.05 or larger than 0.95 indicates a significant difference. Three paths show significant differences. Hypothesis 3 is therefore moderately substantiated. The statistically significant paths are discussed as follows.

Table 10. Comparing Paths using PLS-MGA

\begin{tabular}{lcc}
\hline PLS-MGA & $\begin{array}{c}\text { Path Coefficients - } \\
\text { diff ( } \\
\text { Public (2.0) |) }\end{array}$ & $\begin{array}{c}\text { p-Value (Private (1.0) } \\
\text { vs Public (2.0)) }\end{array}$ \\
\hline HumanResDev. -> Results & 0.026 & 0.556 \\
Info\&Analysis -> Results & 0.304 & $\mathbf{0 . 9 5 4}$ \\
Leadership -> HumanResDev. & 0.065 & 0.941 \\
Leadership -> Info\&Analysis & 0.016 & 0.645 \\
Leadership -> MgmtOfProcesses & 0.152 & $\mathbf{0 . 9 8 8}$ \\
Leadership -> StrategicPlanning & 0.047 & 0.782 \\
MgmtOfProcesses -> Results & 0.085 & 0.309 \\
Results -> CustomerSatisf. & 0.05 & 0.752 \\
StrategicPlanning -> Results & 0.325 & $\mathbf{0 . 0 2 3}$ \\
\hline
\end{tabular}


- The path 'Leadership $\rightarrow$ MgmtOfProcesses'. The public organizations have a significantly higher coefficient than private organizations (0.803 versus 0.651 ).

- The path 'Info\&Analysis $\rightarrow$ Result'. For public organizations, the coefficient is positive (0.370), while for private organization it is not statistically different from zero.

- The path 'StrategicPlanning $\rightarrow$ Results'. For public organizations, it is statistically significant and negative $(-0.274)$, while for private organizations it is not significantly different from zero.

The final analysis we conducted is the PLS-IPMA (importance performance matrix analysis), which helped us identify the key driver constructs for creating business 'results'. We chose 'results' as the target construct instead of 'customer satisfaction' because of the model configuration, where 'customer satisfaction' is a direct effect of 'results'. Furthermore, the revised model has taken into account results from customer satisfaction; that is, sub-criterion 7.5 (coded as 'CS5').

The PLS-IPMA is generally useful for highlighting significant areas for improvement. Constructs that have high importance and low performance should have the main focus, while those with low importance and high performance should be reviewed. With respect to the target endogenous construct, the importance value of a construct is obtained from its total effect on the target construct, while the performance value is obtained from the average value of its latent variable scores. The details of PLS-IPMA method can be found in Hock et al. (2010) or Hair et al. (2014). For the weight conversion of each sub-criterion into a value between 0 and 100, the latest point allocation of the SIQ model (SIQ, 2015) is used for the maximum values of each sub-criterion (see Table 1). In the case when the actual maximum value is greater than the allocated point in Table 1 (the maximum possible value), the actual maximum value is used.

The plot for importance (total effects) and performance (average latent scores) is shown in Figure 7. Note that the latent scores are rescaled to a scale of 0-100 as to facilitate comparison among latent constructs measured on different scale levels. In general, we can make the following observations:

- The performance of private organizations is almost always higher than that of public organizations. The performance of 'management of processes' in public organizations is the lowest.

- The most important construct for creating 'results' is 'leadership', for both private and public organizations. However, the performance is quite low.

- For private organizations, 'management of processes' is more important than 'information and analysis', whereas the opposite applies for public organizations.

- 'Human resource development' is an important key driver for creating 'results' and has quite high performance.

- 'Strategic planning' for private organizations has the highest performance, but the lowest importance. 'Strategic planning' for public organizations has higher importance, in terms of its absolute value, than that of private organizations. The performance of 'strategic planning' in both types of organizations is quite high. This requires attention because it is not especially important for 'results', but many organizations performed quite well in this criterion. 


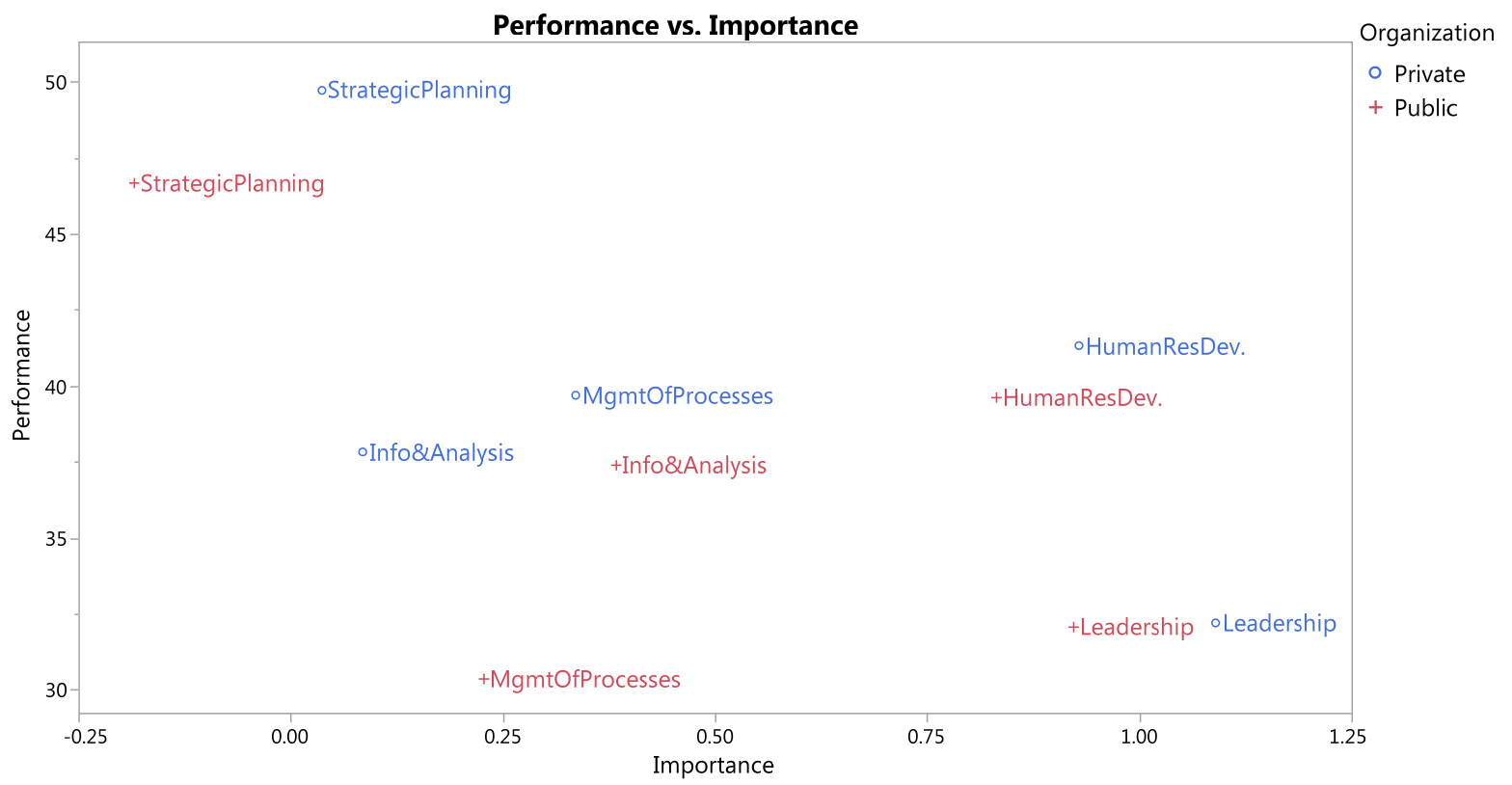

Figure 7. PLS-IPMA map (target construct: Results)

\section{Discussion}

\subsection{The paths in the excellence models for public and private organizations}

With respect to Hypotheses 1 and 2, we failed to find statistical significance in three paths in the SIQ model. Sabella et al. (2014) found that the path from information and analysis to performance ('results' in our study) was significant for their sample. Our study suggests that the information and analysis criterion has an impact on the results criterion for public organizations, but that impact was not significant for private organizations. Second, the path coefficient of the path 'strategy planning to results' is near zero and negative for private and public organizations, respectively. This could be related to the fact that many public organizations do not have the same strategic freedom as private organizations because some of their strategic goals are determined by the political system (Eskildsen et al., 2004; Elg et al., 2015). This can imply that public organizations, in particular, should spend less energy and resources on strategic planning as they seem to lose sight of the goal of achieving good results. In private organizations, there seems to be no guarantee that good planning will lead to a good result. The impact of strategic management ('strategy planning' in our study) on the results was shown in the study by Su et al. (2003).

Lastly, the data did not significantly support the 'management of processes' to 'results' path for public organizations. This path has been empirically shown in other articles that did not analyze public and private differences (Curkovic et al., 2000; Fotopoulos \& Psomas, 2010; Sabella et al., 2014; Calvo-Mora et al., 2014). Furthermore, Eriksson (2016) has argued that the process management models and framework fit public organizations badly. The present study supports the findings by Eriksson (2016), given that no significant effect from the process management on the results could be found for public organizations.

On the other hand, several paths were empirically shown to be valid both for private and public organizations and in accordance with other studies. The leadership criterion has an impact on information and analysis (Su et al., 2003; Moon et al., 2011), strategic planning (Jayamaha et al., 2008; Heras-Saizarbitoria et al., 2012), human resource development (Gómez-Gómez et 
al., 2011; Heras-Saizarbitoria et al., 2012), and management of processes (Moon et al., 2011), for both private and public organizations. Moreover, the human resource development criterion has an impact on the results criterion (Calvo-Mora et al., 2014), and the results criterion has an impact on the customer satisfaction criterion, both for private and public organizations.

\subsection{Are there any differences between public and private?}

The third hypothesis and its two connected hypotheses investigate whether there are significant differences in the relationship among the criteria between private and public organizations. Although there have been studies of private and public differences (Perry \& Rainey, 1988; Boyne, 2002; Hvidman \& Andersen, 2014), our approach is unique in terms of using applicants' score data that originate from business excellence models. Surprisingly, we only found three significant differences between public and private organizations when studying the relations between the criteria. Although earlier research has pointed out general differences between public and private organizations (see Section 2.2), it seems like most of the paths in the SIQ model do not differ significantly. One explanation could be that our sample size is not large enough to substantiate the effects. Our study is thus among the few which address how the differences between private and public organizations are manifested in the paths of business excellence models. With regard to the detected differences, three points can be made. First, the information and analysis effect on results was different between public and private organizations in the sense that the relation was significantly stronger for public organizations (which contradicts Hypothesis 3b). Hence, it seems like there is more to gain in terms of results for public organizations to succed with managing the information and analysis. Information and analysis can play an important part in the more participative culture that the public organizations seem to have; see Hansen and Villadsen (2010).

Second, the path from leadership to management of processes is also significantly stronger for public organizations than for their private counterparts. It appears that the leaders play a more important role in the management of processes for public organizations (which supports Hypothesis 3a). As described in Section 2, Andersen (2010) found that public managers in Sweden have a more change-oriented leadership style (for example, pushing for growth, initiating new projects, offering ideas about new and different ways of doing things, giving thoughts and plans for the future), which could explain why the path is stronger in public organizations.

Third, the impact of strategic planning on results is significantly stronger in public organizations than in private organizations, but with a negative direction. In other words, the high scores in strategic planning are associated with low scores in results for public organizations, and vice versa. This still supports Hypothesis $3 b$ because the impact of strategic planning on results is positively stronger for private organizations than for public ones. Boyne's (2002) claim that bureaucracy is higher in public organizations than in private ones could partly explain why high performance in strategic planning may lead to low performance in business results. For private organizations, high performance in strategic planning is not always associated with high performance in business results.

\section{Conclusions}

The present study aimed to explore the differences between public and private organizations in the paths of business excellence models and to identify the key drivers for creating business results and customer satisfaction. In line with previous research, we confirmed that leadership is a very strong predictor of human resource development, information and analysis, 
management of processes, and strategic planning. It is also the most important driver of business 'results'. Unfortunately, most of the organizations did not score high with respect to this criterion. In general, it is difficult to explain or predict the variation in business 'results' for private and public organizations. The performance of private organizations is almost always higher than that of public ones, in all criteria. However, the variation in private organizations' endogenous constructs is more difficult to explain or predict than that in public organizations.

Specifically, we can summarize our findings on the differences between public and private organizations into three points. First, the effect of 'leadership' on 'management of processes' is significantly higher in public organizations than in private ones. However, in public organizations, the 'management of processes' does not really predict business 'results' and the effect is not statistically significant either. Second, for private organizations, 'management of processes' is a more important driver for creating business results than 'information and analysis', whereas the reverse applies for public organizations. This may imply that, when trying to achieve excellence, private organizations should focus primarily on 'management of processes' and public organizations should focus on 'information and analysis'. Third, the effect of strategic planning on creating business results is negative for public organizations and remains inconclusive, due to insufficient evidence, for private organizations. In other words, a high performance in strategic planning may lead to a low performance in business results in public organizations. Most of the organizations have high scores in this criterion despite the fact that it is among the least important criteria for predicting business results. A practical implication is that the criterion 'strategic planning' should be reviewed in the SIQ excellence model.

A limitation of the present study is that it only covers a relatively small geographical region, which implies that our results cannot be generalized. Different national cultures may have different results when using excellence models (Flynn and Saladin, 2006). Another limitation may be the use of applicants' scores data over the years and the reflective measurement model. The longitudinal effect over the two decades, such as the effect of SIQ model diffusion on the characteristics of the organizations applying for the award over time or socio-economic changes in the country during global recession in 2008, could be worth investigating. With respect to the reflective measurement model, another way to look at the main criteria is that they are derived from aggregating the sub-criteria; in this case, it could be interesting to assume a formative measurement model.

In sum, we hope that this study will enhance the knowledge regarding the use of business excellence models in private and public organizations and support the move toward more tailormade models for specific sectors. We also hope that this research will contribute to a deeper theoretical understanding on business excellence and quality management, and especially how business excellence can be contextualized to better fit different organizations.

\section{Acknowledgement}

The authors are grateful to the Swedish Institute for Quality for providing its resources, past data, and partial funding to carry out this research.

\section{REFERENCES}

Andersen, J. A. (2010). Public versus private managers: How public and private managers differ in leadership behavior. Public Administration Review, 70(1), 131-141.

Boland, T., \& Fowler, A. (2000). A systems perspective of performance management in public sector organisations. 
International Journal of Public Sector Management, 13(5), 417-446.

Bollen, K.A. (1989), Structural Equations with Latent Variables, John Wiley \& Sons, Chichester.

Bou-Llusar, J. C., Escrig-Tena, A. B., Roca-Puig, V., \& Beltrán-Martín, I. (2009). An empirical assessment of the EFQM Excellence Model: Evaluation as a TQM framework relative to the MBNQA Model. Journal of Operations Management, 27(1), 1-22.

Boulter, L., Bendell, T., \& Dahlgaard, J. (2013). Total quality beyond North America: A comparative analysis of the performance of European Excellence Award winners. International Journal of Operations \& Production Management, 33(2), 197-215.

Boyne, G. A. (2002), Public and Private Management: What's the Difference? Journal of Management Studies, 39, 97-122.

Calvo-Mora, A., Leal, A., \& Roldán, J. L. (2005). Relationships between the EFQM model criteria: a study in Spanish universities. Total Quality Management \& Business Excellence, 16(6), 741-770.

Calvo-Mora, A., Picón, A., Ruiz, C., \& Cauzo, L. (2013). The relationships between soft-hard TQM factors and key business results. International Journal of Operations \& Production Management, 34(1), 115-143.

Calvo-Mora, A., Ruiz-Moreno, C., Picón-Berjoyo, A. \& Cauzo-Bottala, L. (2014). Mediation effect of TQM technical factors in excellence management systems, Journal of Business Research, 67(5), 769-774.

Chin, W. W. (1998). Issues and Opinion on Structural Equation Modeling. Management Information Systems Quarterly, 22(1), 3.

Curkovic, S., Melnyk, S., Calantone, R., \& Handfield, R. (2000). Validating the Malcolm Baldrige National Quality Award framework through structural equation modelling. International Journal of Production Research, 38(4), 765-791.

Dean, M. B. and Helm, M. M. (1996). The implementation of Total Quality Management into public sector agencies. A case study of the Tennessee Valley Authority. Benchmarking for Quality Management \& Technology, 3(1), 50-64.

Dixit, A. (1997). Power of incentives in private versus public organizations. The American Economic Review, 87(2), 378-382.

Elg, M., Wihlborg, E., \& Örnerheim, M. (2015). Public quality - for whom and how? Integrating public core values with quality management. Total Quality Management \& Business Excellence, DOI: 10.1080/14783363.2015.1087841.

Eriksson, H. \& Hansson, J. (2003). The impact of TQM on financial performance. Measuring Business Excellence, $7(1), 36-50$.

Eriksson, H. (2016). Outcome of quality management practices. Differences among public and private, manufacturing and service, SME and large organisations. International Journal of Quality and Reliability Management. 33(9).

Eriksson, H. Gremyr, I, Garvare R. Bergquist, B., Fundin, A., Wiklund, H., Wester M. \& Sörqvist, L. (2016). Exploring Quality Challenges and the Validity of Excellence Models. International Journal of Operations and Production Management 36(10).

Eskildsen, J. K., Kristensen, K., \& Jørn Juhl, H. 2004. Private versus public sector excellence. The TQM Magazine, 16(1), 50-56.

Flynn, B. B., \& Saladin, B. (2006). Relevance of Baldrige constructs in an international context: A study of national culture. Journal of Operations Management, 24(5), 583-603.

Fotopoulos, C. V. and Psomas, E. L. (2010). The structural relationships between TQM factors and organizational performance. Total Quality Management \& Business Excellence, 22(5), 539-552.

Ghobadian, A. and Woo, H. S. (1994). Characteristics, benefits and shortcomings of four major quality awards. International Journal of Quality and Reliability Management, 13(2), 10-44.

Gómez-Gómez, J., Martínez-Costa, M., \& Martínez-Lorente, A. R. (2011). A critical evaluation of the EFQM model. International Journal of Quality \& Reliability Management, 28(5), 484-502.

Hair, J. F., Hult, G. T. M., Ringle, C. M., \& Sarstedt, M. (2014). A Primer on Partial Least Squares Structural Equation Modeling (PLS-SEM). Thousand Oaks: Sage. 
Hair, J. F., Sarstedt, M., Ringle, C. M., \& Mena, J. A. (2012). An assessment of the use of partial least squares structural equation modeling in marketing research. Journal of the Academy of Marketing Science, 40(3), 414-433.

Hansen, J. R., \& Villadsen, A. R. (2010). Comparing public and private managers' leadership styles: Understanding the role of job context. International Public Management Journal, 13(3), 247-274.

Hendricks, K. B. and Singhal, V. R. (1997). Does implementing an effective TQM program actually improve operating performance? Empirical evidence from firms that have won quality awards. Management Science, 43(9), 1258-1274.

Henseler, J., Ringle, C. M., \& Sarstedt, M. (2015). A new criterion for assessing discriminant validity in variance based structural equation modeling. Journal of the Academy of Marketing Science, 43(1), 1-21.

Henseler, J., Ringle, C. M., \& Sinkovics, R. R. (2009). The use of partial least squares path modeling in international marketing. Advances in International Marketing (AIM), 20, 277-320.

Heras-Saizarbitoria, I., Marimon, F., \& Casadesus, M. (2012). An empirical study of the relationships within the categories of the EFQM model. Total Quality Management \& Business Excellence, 23(5-6), 523-540.

Hock, C., Ringle, C. M., \& Sarstedt, M. (2010). Management of multi-purpose stadiums: Importance and performance measurement of service interfaces. International Journal of Services Technology and Management, 14(2-3), 188-207.

Hvidman, U., \& Andersen, S. C. (2014). Impact of performance management in public and private organizations. Journal of Public Administration Research and Theory, 24(1), 35-58.

Jayamaha, N. P., Grigg, N. P., \& Mann, R. S. (2008). Empirical validity of Baldrige criteria: New Zealand evidence. International Journal of Quality \& Reliability Management, 25(5), 477-493.

Lee, S. M., Rho, B. H., \& Lee, S. G. (2003). Impact of Malcolm Baldrige National Quality Award criteria on organizational quality performance. International Journal of Production Research, 41(9), 2003-2020.

Lyons, S. T., Duxbury, L. E., \& Higgins, C. A. (2006). A comparison of the values and commitment of private sector, public sector, and parapublic sector employees. Public Administration Review, 66(4), 605-618.

Meyer, S. M., \& Collier, D. A. (2001). An empirical test of the causal relationships in the Baldrige Health Care Pilot Criteria. Journal of Operations Management, 19(4), 403-426.

Moon, J. Y., Lee, S. C., Yong-Seung, P., \& Suh, Y. H. (2011). A study on the causal relationships in the Korean National Quality Award model. Total Quality Management \& Business Excellence, 22(7), 705-726.

Perry, J. L., and Rainey H. G. (1988). The public-private distinction in organization theory: A critique and research strategy. The Academy of Management Review, 13, 182-201.

Raharjo, H., Guglielmetti Mugion, R., Eriksson, H., Gremyr, I., Di Pietro, L., \& Renzi, M. F. (2015). Excellence models in the public sector. Relationships between enablers and results. International Journal of Quality and Service Sciences, 7(1), 120-135.

Rainey, H. G., Backoff, R. W., \& Levine, C. H. (1976). Comparing public and private organizations. Public Administration Review, 36(2), 233-244.

Rigdon, E. E., Ringle, C. M., Sarstedt, M., \& Gudergan, S. P. (2011). Assessing heterogeneity in customer satisfaction studies: across industry similarities and within industry differences. Advances in International Marketing, 22, 169-194.

Ringle, C. M., Wende, S., \& Becker, J.-M. (2015). “SmartPLS 3”. Boenningstedt: SmartPLS GmbH, http://www.smartpls.com.

Roy, S., Tarafdar, M., Ragu-Nathan, T. S., \& Marsillac, E. (2012). The effect of misspecification of reflective and formative constructs in operations and manufacturing management research. Electronic Journal of Business Research Methods, 10(1), 34-52.

Sabella, A., Kashou, R. \& Omran, O. (2014), Quality Management Practices and their relationship to organizational performance, International Journal of Operations and Production Management, 34(12), 14871505.

Samson, D., \& Terziovski, M. (1999). The relationship between Total Quality Management practices and operational performance. Journal of Operations Management, 17(4), 393-409. 
Sarstedt, M., Henseler, J., and Ringle, C. M. (2011). Multi-Group Analysis in Partial Least Squares (PLS) Path Modeling: Alternative Methods and Empirical Results. Advances in International Marketing, 22, $195-218$.

Sarstedt, M., Ringle, C. M., Henseler, J., \& Hair, J. F. (2014). On the emancipation of PLS-SEM: A commentary on Rigdon (2012). Long Range Planning, 47(3), 154-160.

Schloderer, M. P., Sarstedt, M., \& Ringle, C. M. (2014). The relevance of reputation in the non-profit sector: the moderating effect of socio-demographic characteristics. International Journal of Non-profit and Voluntary Sector Marketing, 19(2), 110-126.

SIQ (2015). SIQ Model for Performance Excellence, Swedish Institute for Quality (SIQ), Gothenburg, Sweden.

Sousa, R., \& Voss, C. A. (2001). Quality Management: Universal or context dependent? Production and Operations Management, 10(4), 383-404.

Su, C. T., Li, S. C., \& Su, C. H. (2003). An empirical study of the Taiwan National Quality Award causal model. Total Quality Management and Business Excellence, 14(8), 875-893.

Tan, K. C., Wong, M. F., Mehta, T. \& Khoo, H. H. (2003). Factors affecting the development of national quality awards, Measuring Business Excellence, 7(3), 37-45.

Xiang, J.Y., He, Z., Ho Suh, Y., Young Moon, J., \& Fen Liu, Y. (2010). An empirical investigation of the China quality award causal model. Asian Journal on Quality, 11(1), 49-68. 